\section{Impact of High Pressure on the Infusion of Curcuminoids in Pineapple Slices}

\author{
Jincy M George ${ }^{1,2}$ and Navin K Rastogi $i^{1,2^{*}}$ \\ ${ }^{1}$ ACSIR, Central Food Technological Research Institute, Mysore, India
}

${ }^{2}$ Department of Food Engineering, Central Food Technological Research Institute, Mysore, India by many research workers. However, it is relatively a slow and time consuming process. Hence, a few techniques have been acknowledged in order to enhance the rate of osmotically induced mass transfer that include partial vacuum $[10,11]$, pulsed vacuum [12], high pressure [13-15], high intensity pulsed electric field [16,17], ohmic heating $[18,19]$ or ultrasound [20-23]. Application of high pressure treatment accelerated the diffusion of bioactive components into the solid food due to cell membranes permeabilisation resulting in decline in the resistance to infusion $[24,25]$. The application of high pressure pretreatment was described to increase the water and solute diffusion during osmotic dehydration of pineapples, potato, glutinous rice and turkey breast [26-29]. Sila et al., [30] demonstrated that combined effect of high pressure treatment and $\mathrm{CaCl}_{2}$ treatment improved the texture of carrots during thermal processing. High pressure-assisted infusion of pectin methyl esterase and calcium chloride in strawberry was shown to improve the firmness [13,31]. Mahadevan et al., [32] indicated that high pressure pretreatment increased infusion of quercetin by 3 times into cranberries as compared to untreated ones.

Incorporation of synthetic antioxidants like Butylated Hydroxyanisole (BHA) and Butylated Hydroxy Toluene (BHT) are restricted by legislative laws and regulations due to carcinogenic effects [33]. Therefore, there has been an increasing trend to use natural antioxidants over the synthetic ones. Turmeric (Curcuma longa $\mathrm{L}$.) is considered as one of the main source of antioxidants curcuminoids namely Curcumin, Demethoxycurcumin and Bisdemethoxycurcumin [34]. It can improve the visual appearance, delectableness and prolong the storage period of food products [35]. The recommended daily intake of curcuminoids is $0.1 \mathrm{mg} / \mathrm{kg}$ body weight [36]. Several biological activities have been also reported in turmeric such as antioxidant, anti-inflammatory, anti-psoriatic, anti-diabetic, antibacterial, and anticancer properties [37-42]. Exhilarated with this idea of to develop pineapple slices with enhanced nutrition and color, it was opined desirable to infuse natural antioxidant (curcuminoids) to enhance the nutrition profile. The present study indicated that high pressure pretreatment enhanced the diffusion coefficients of curcuminoids in pineapple slices. The process could provide great opportunities for food manufacturers to develop value-added products similar to the fresh one and with enhanced nutritional and quality attributes.

The main objectives of the present work were (i) to study the effect of high pressure treatment on the infusion of curcuminoids into pineapple slices, (ii) to determine the diffusivity of water, solute as well as curcuminoids, and (iii) to assess the possible improvement of mass transfer kinetics osmotic treatment due to high pressure treatment.

\section{Materials and Methods}

\section{Raw materials}

Pineapples (Ananas comsus L. (Merr.)) were purchased from a local super market in Mysore and stored in cold storage rooms $\left(4 \pm 1^{\circ} \mathrm{C}\right.$ and $90 \% \mathrm{RH})$ and drawn as and when required for the experiment. The pineapple, after peeling and coring, was cut into $15 \times 15 \times 10 \mathrm{~mm}$ slices. 


\section{Sample preparation}

The water soluble infusate was prepared by suspending $3 \%$ curcumin (Sigma-Aldrich) containing propylene glycol and polysorbate in the ratio of 1:1 [43].The moisture content of pineapple as determined by vacuum drying $\left(60^{\circ} \mathrm{C}\right.$ for $\left.24 \mathrm{~h}\right)$ was $85 \%$ on a wet weight basis. Sucrose was used as the osmotic agent.

\section{High pressure pretreatment}

The pineapple slices were high pressure treated in a cylindrical pressure vessel (Volume 1L, maximum working pressure $400 \mathrm{MPa}$, M/s Khoday Hydraulics Ltd., Mumbai). The time require to reach maximum treatment pressure was $10 \mathrm{~min}$, and decompression took $10 \mathrm{~s}$. The samples were packaged along with the impregnating solution (containing $0.13 \mathrm{~g} / 100 \mathrm{ml}$ infusate) in the ratio of 1:3 in LDPE (Low Density Polyethylene) pouches. The pouches were heat sealed and the samples were treated at $350 \mathrm{MPa}$ for $10 \mathrm{~min}$. The processing conditions were selected based on our earlier work [26]. The water was taken as a medium for transmitting pressure.

\section{Osmotic treatments}

High pressure treated samples were subjected to osmotic treatment over a range of sugar concentration $\left(0\right.$ to $\left.70^{\circ} \mathrm{Brix}\right)$. The osmotic solutions were added with the infusate containing $0.13 \mathrm{~g} / 100 \mathrm{ml}$. The solid to liquid was maintained at 1:5 to make ensure that the concentration of osmotic solution did not change significantly. At the end of every hour of immersion time, the samples were withdrawn, rinsed in water and blotted gently, weighed and then dried in a vacuum oven $\left(60^{\circ} \mathrm{C}\right.$ for $\left.24 \mathrm{~h}\right)$. Moisture and solid content were determined and expressed in terms of $\mathrm{kg}$ of water $/ \mathrm{kg}$ of initial dry solid and $\mathrm{kg}$ of solids/ $\mathrm{kg}$ of initial dry solid, respectively. All the experiments were done three times and the average of the three value was reported.

\section{Estimation of curcuminoids content}

The curcuminoids content in pineapple slices were estimated as per ASTA [44] procedure based on the spectroscopic analysis.

\section{Moisture, solid or curcuminoids diffusion coefficients}

Fick's second law solution for diffusion from an infinite flat plate configuration (thickness $2 \mathrm{a}$ ) results in the following equation for mass transfer $[45,46]$ :

$$
X_{i}=\frac{\left(x_{t i}-x_{\infty i}\right)}{\left(x_{o i}-x_{\infty i}\right)}=\sum_{n=1}^{\infty} C_{n} \exp \left[-D_{e i} t q_{n}{ }^{2}\left(\frac{1}{a^{2}}\right)\right]
$$

Fourier number (for moisture and solid or curcuminoids, $\mathrm{F}_{\mathrm{oi}}$ ) is defined as $\mathrm{D}_{\text {eit }} / \mathrm{a} 2$ and substituting the value into Eq. (1) results in the Eq (2):

$$
X_{i}=\frac{\left(x_{t i}-x_{\infty i}\right)}{\left(x_{o i}-x_{\infty i}\right)}=\sum_{n=1}^{\infty} C_{n} \exp \left[-F_{o i} q_{n}{ }^{2}\right]
$$

Where $\mathrm{C}_{\mathrm{n}}=2 \alpha(1+\alpha) /\left(1+\alpha+\alpha^{2} \mathrm{q}_{\mathrm{n}}^{2}\right)$ and $q_{n}$ 's are the positive roots of the equation $\tan \left(\mathrm{q}_{\mathrm{u}}\right)=-\alpha \mathrm{qn}$. $\mathrm{X}_{\mathrm{i}}$ is the dimensionless moisture ratio (when $\mathrm{i}=\mathrm{m}$ ) or solid ratio (when $\mathrm{i}=\mathrm{s}$ ); the subscripts $o, \infty$ and $t$ represent the initial, at equilibrium and at any time concentrations; the subscript ' $i$ ' takes values ' $m$ ', ' $s$ ' and ' $c$ ' for moisture, solid or curcuminoids content, respectively; $\mathrm{D}_{\mathrm{ei}}$ is the diffusion coefficient; and Here, $\alpha$ is the volume ratio of solution to that of solid. Eq. (2) was graphically represented by plotting log (Xi) against Fourier number
$\left(\mathrm{F}_{\mathrm{oi}}\right.$, Figure 1) and $\left[\mathrm{d}\left(\log \mathrm{X}_{\mathrm{i}}\right) / \mathrm{dF}_{\mathrm{oi}}\right]$ is the slope of the theoretical diffusion line and which was found to be 1.075 [46].

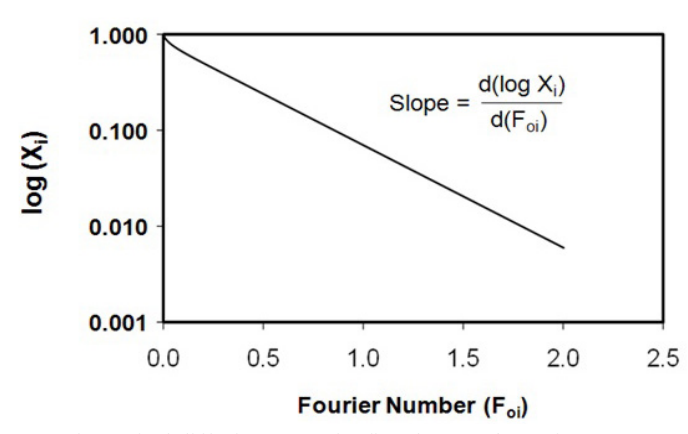

Figure 1: Theoretical diffusion curve for flat plate configuration as per Eq. (4).

The following equation for mass transfer can be written by considering the equilibrium approach to mass transfer [47]:

$$
-\frac{\mathrm{dx}_{\mathrm{i}}}{\mathrm{dt}}=\mathrm{k}_{\mathrm{i}}\left(\mathrm{x}_{\mathrm{ti}}-\mathrm{x}_{\infty \mathrm{i}}\right)
$$

Where $\mathrm{k}_{\mathrm{i}}$ is the mass transfer coefficients. Integration of Eq. (3), with the appropriate limits, resulted in the following equations:

$$
\ln \frac{\left(x_{t i}-x_{\infty i}\right)}{\left(x_{o i}-x_{\infty i}\right)}=\ln X_{i}=-k_{i} t
$$

The differentiation of the Eq. (4) resulted in the Eq. (5), which was used to calculate the experimental slopes.

$$
\frac{d}{d t}\left(\log X_{i}\right)=-\frac{k_{i}}{2.3025}
$$

In order to obtain mass transfer coefficients $\left(\mathrm{k}_{\mathrm{i}}\right)$ and equilibrium values $\left(\mathrm{x}_{\infty \mathrm{i}}\right)$, the rate of change of moisture, solid or curcuminoids content was plotted against av. moisture, solid or curcuminoids content, respectively [46]

Based on the infinite flat sheet, $\mathrm{D}_{\mathrm{e}}$ values were determined from the following equation $[46,47]$ :

$$
D_{e i}=\left[\frac{d\left(\log X_{i}\right) / d t}{d\left(\log X_{i}\right) / d F_{o i}}\right] \cdot a^{2}
$$

\section{Determination of DPPH radical Scavenging Activity (SA)}

The free radical scavenging activity of control and high pressure treated pineapple slices was evaluated using the stable radical DPPH as described by [48].

\section{Texture determination}

Maximum compressive force was measured using Texture Analyzer (LLOYD-LR-5K, Surrey, UK)and used as a measure of hardness (probe cone of $30^{\circ}$ angle, penetration depth of $1 \mathrm{~mm}$, loading speed $5 \mathrm{~mm} / \mathrm{s}$, and load cell capacity $25 \mathrm{~kg}$ ).

\section{Statistical analysis}

The statistical significance between groups were determined using 
a one-way Analysis of Variance (ANOVA) followed by Turkey-Kramer test, with $\mathrm{p} \leq 0.05$ indicating significance, using MS-Excel. All the experiments were performed three times and average values were recorded.

\section{Result and Discussion}

\section{Impact of osmotic treatment on moisture, solids and cur- cuminoids mass transfer}

The application of high pressure $(350 \mathrm{MPa} / 10 \mathrm{~min})$ alters the moisture, solid and curcuminoids during the course of osmotic treatment $(0$ to $5 \mathrm{~h})$ for different concentrations of osmotic solution (0$70^{\circ}$ Brix). The variations in moisture, solid and curcuminoids with immersion time are presented in figures 2-4. The rate of change of moisture, solid and curcuminoids $\left(\mathrm{dx}_{\mathrm{m}} / \mathrm{dt}, \mathrm{dx}_{\mathrm{s}} / \mathrm{dt}, \mathrm{dx}_{\mathrm{c}} / \mathrm{dt}\right)$ contents obtained from figures 2-4 and plotted against the average moisture, solid and curcuminoids $\left(A_{m}, A_{s}, A_{c}\right)$ contents, respectively to obtain mass transfer coefficients for moisture, solid and curcuminoids $\left(\mathrm{k}_{\mathrm{m}}, \mathrm{k}_{\mathrm{s}}, \mathrm{k}_{\mathrm{c}}\right)$ as well as equilibrium moisture, solid, and curcuminoids $\left(\mathrm{x}_{\infty \mathrm{m}}, \mathrm{x}_{\infty \mathrm{s}}\right.$ and $\left.\mathrm{x}_{\infty c}\right)$ from the slope and intercept of these plots. The values are presented in (Table 1).

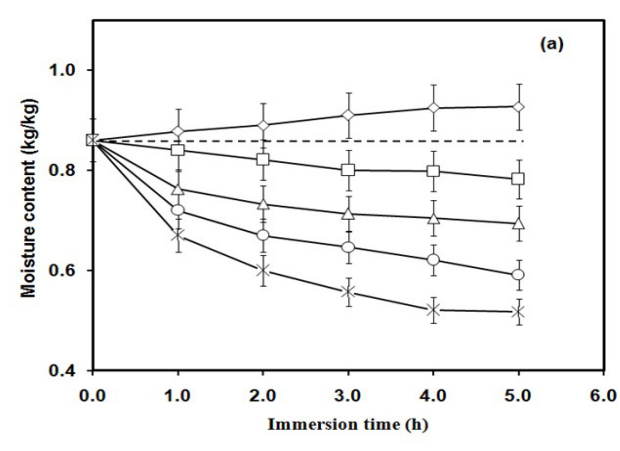

$\rightarrow 0^{\circ}$ Brix $\quad-\square-40^{\circ}$ Brix $\quad-\square-50^{\circ}$ Brix $\quad-6-60^{\circ}$ Brix $\quad-*-70^{\circ}$ Brix

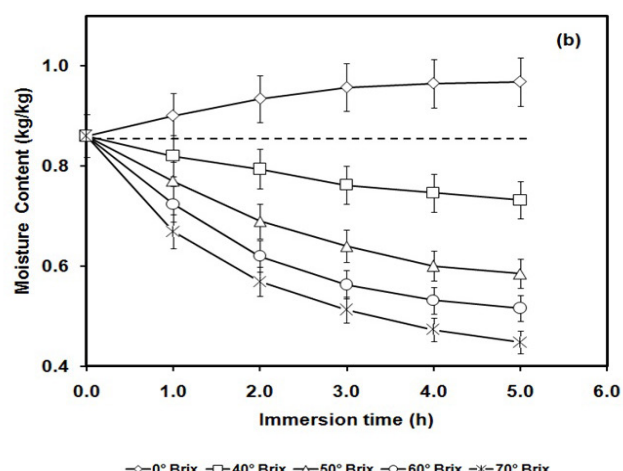

Figure 2: Variation of moisture content during (a) osmotic dehydration assisted infusion of pine apple sample, (b) high pressure-assisted osmotic treated pineapple sample for various concentrations of osmotic solution $\left(0-70^{\circ} \mathrm{Brix}\right)$ at $350 \mathrm{MPa}$ for $10 \mathrm{~min}$

The pineapple slices subjected to $0^{\circ}$ Brix solution containing aqueous of curcuminoids resulted in diffusion of water into pineapple slices due to the higher osmotic pressure inside the food matrix in comparison to the osmotic medium (Figure 2a). The high pressure treatment $(350 \mathrm{MPa})$ resulted in rise in moisture gain (Figure $2 \mathrm{~b}$ ). At the same time, subjecting the pineapple slices in $0^{\circ}$ Brix solution (water) it also led to diffusion of solids from pineapple into the osmotic medium (Figure 3a). Its extent was slightly increased due to application of high pressure (Figure $3 b$ ). The pressure pretreatment was found to result in rise in diffusivity for moisture infusion and solid loss from $0.12 \times 10^{-9} \mathrm{~m}^{2} / \mathrm{s}$ to $0.55 \times 10^{-9} \mathrm{~m}^{2} / \mathrm{s}$ and from $0.26 \times 10^{-9} \mathrm{~m}^{2} / \mathrm{s}$ to $0.40 \times 10^{-9} \mathrm{~m}^{2} / \mathrm{s}$, respectively.
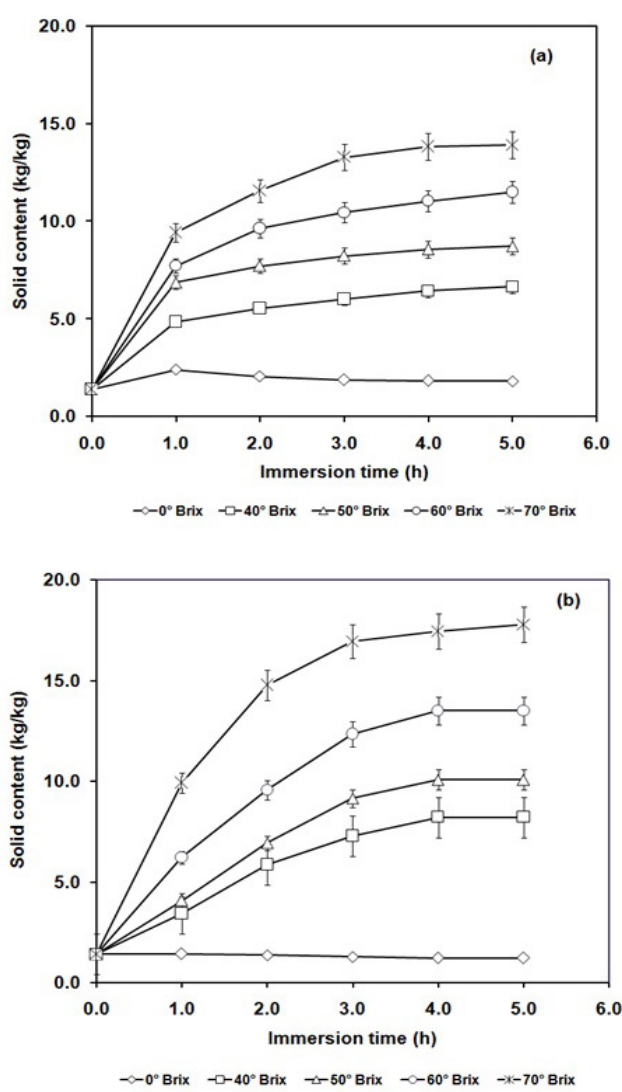

Figure 3: Variation of solid content during (a) osmotic dehydration assisted infusion of pineapple sample, (b) high pressure-assisted osmotic treated pineapple sample for various concentrations of osmotic solution $\left(0-70^{\circ} \mathrm{Brix}\right)$ at $350 \mathrm{MPa}$ for $10 \mathrm{~min}$.

The pineapple slices subjected to 40 to $70^{\circ}$ Brix osmotic solution containing water soluble curcuminoids resulted in the reversal of direction of mass transfer. The diffusion of water took place from pineapple slices to osmotic solution and solids were diffused from osmotic solution to the pineapple because of higher osmotic pressure of osmotic solutions (Figures 2a, 3a). Further, high pressure treatment resulted in increased moisture and solute mass transfers (Figures $2 b$, $3 b)$. For instance, for $70^{\circ}$ Brix concentration of surrounding solution, the application of high pressure $(350 \mathrm{MPa})$ increased the moisture diffusion coefficient from $1.17 \times 10^{-9} \mathrm{~m}^{2} / \mathrm{s}$ to $1.68 \times 10^{-09} \mathrm{~m}^{2} / \mathrm{s}$ and solid diffusion coefficient were increased from $1.42 \times 10^{-9} \mathrm{~m}^{2} / \mathrm{s}$ to $1.75 \times$ $10^{-09} \mathrm{~m}^{2} / \mathrm{s}$ (Table 1 ).

As far as the infusion of curcuminoids is concerned, the increase in concentration of osmotic solution from 0 to $70^{\circ}$ Brix resulted in decrease in diffusion coefficient for curcuminoids diffusion from $0.86 \times 10^{-09}$ to $0.31 \times 10^{-09} \mathrm{~m}^{2} / \mathrm{s}$ (Figure 4a, Table 1). Further, the application of high pressure resulted in instant increase in curcuminoids content up to $22.30 \pm 0.31 \mathrm{mg} / 100 \mathrm{~g}$. The diffusion coefficient value for curcuminoids diffusion for $0^{\circ}$ Brix surrounding solution was found to increase from $0.86 \times 10^{-09}$ to $1.53 \times 10^{-09} \mathrm{~m}^{2} / \mathrm{s}$ (Figure 4, Table 1). 
Further, increase in concentration of osmotic solution from 40 to $70^{\circ}$ Brix of high pressure treated pineapple resulted in decrease in the curcuminoids after instant increase to $22.30 \pm 0.17 \mathrm{mg} / 100 \mathrm{~g}$ and the corresponding diffusion coefficient values were decreased from 1.42 to $0.64 \times 10^{-09} \mathrm{~m}^{2} / \mathrm{s}$ (Figure 4, Table 1). The values in the parenthesis indicate a reversal in direction of mass transfer with corresponding increase in the surrounding solution concentration (Table 1). However, the curcuminoids contents were always higher in pressure treated pineapple as compared to control sample.
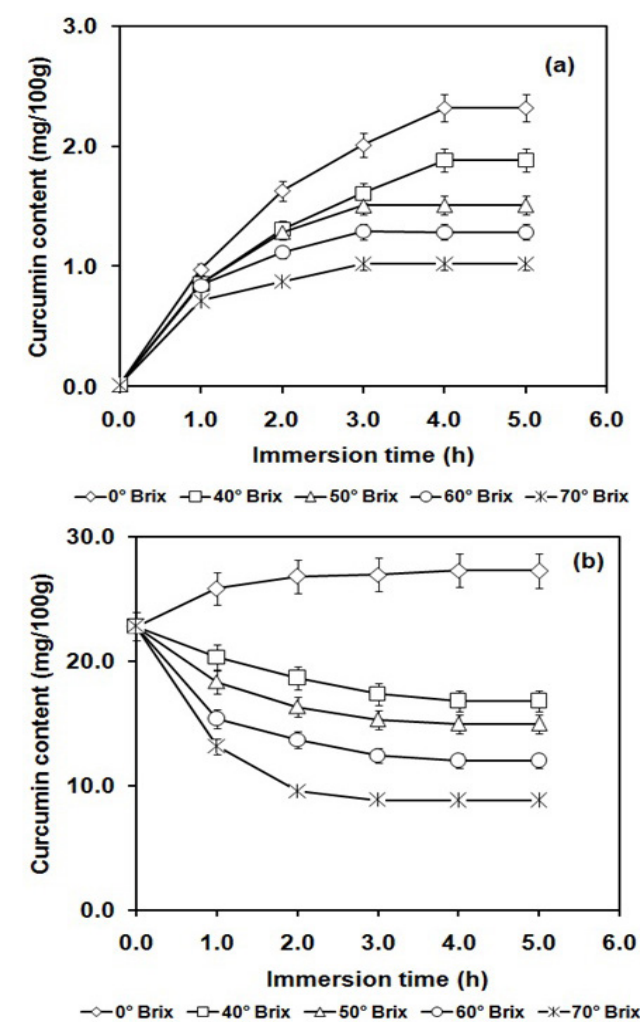

Figure 4: Variation of curcumin content (a) at atmospheric pressure for various concentrations of osmotic solution $\left(0-70^{\circ} \mathrm{Brix}\right)(\mathrm{b})$ high pressure assisted infusion for various concentrations of osmotic solution $\left(0-70^{\circ} \mathrm{Brix}\right)$ at $350 \mathrm{MPa}$ for $10 \mathrm{~min}$.

When water was used the surrounding solution, the total grape phenolic compounds impregnated in model food system was almost found to be twice as compared to osmotic solution (sucrose $50 \mathrm{~g} / 100 \mathrm{~g}$ ) $[4,5]$. The optimum condition for infusion was found when the surrounding medium had minimum concentration. Similarly, George et al., [15] also showed that the infusion of anthocyanin under high hydrostatic pressure $(250 \mathrm{MPa} / 10 \mathrm{~min})$ was nearly 3 folds higher as compared to ambient conditions $(0.1 \mathrm{MPa})$ when pure water $\left(0^{\circ} \mathrm{Brix}\right)$ was used as osmotic solution.

\section{Impact of high pressure treatment on curcuminoids infu- sion, antioxidant activity and texture}

The curcuminoids content and antioxidant activity of fresh pineapple and the samples subjected to $0^{\circ}$ Brix with or without pressure treatment after $5.0 \mathrm{~h}$ of immersion are shown in figure $5 \mathrm{a}$, which indicated that the treatment with surrounding solution containing pure water $\left(0^{\circ}\right.$ Brix $)$ resulted in $2.19 \pm 0.23 \mathrm{mg} / 100 \mathrm{~g}$ of curcuminoids content that was further enhanced to $27.32 \pm 0.27 \mathrm{mg} / 100 \mathrm{~g}$ by the application of the pressure treatment. The antioxidant activity of the pineapple samples was also higher wherever the curcuminoids content was higher indicating infused curcuminoids in pineapple sample led to the enhancement of antioxidant activity. Lin et al., [49] also demonstrated that minimum concentration of the surrounding medium resulted in higher fortification of Vitamin E content in fresh pears. The higher infusion of curcuminoids was found to be related with the minimum compressive force (Figure 5b). The decrease in compressive force with on subjecting to high pressure may be related to the permeabilisation of cells leading to reduced mass transfer resistance thereby resulting in higher infusion. In case of pineapple slices high pressure treatment results in decrease in compressive force [26]. These results clearly indicate that the high pressure pretreatment is one of the potential methods to enhance the infusion of bioactive compounds.
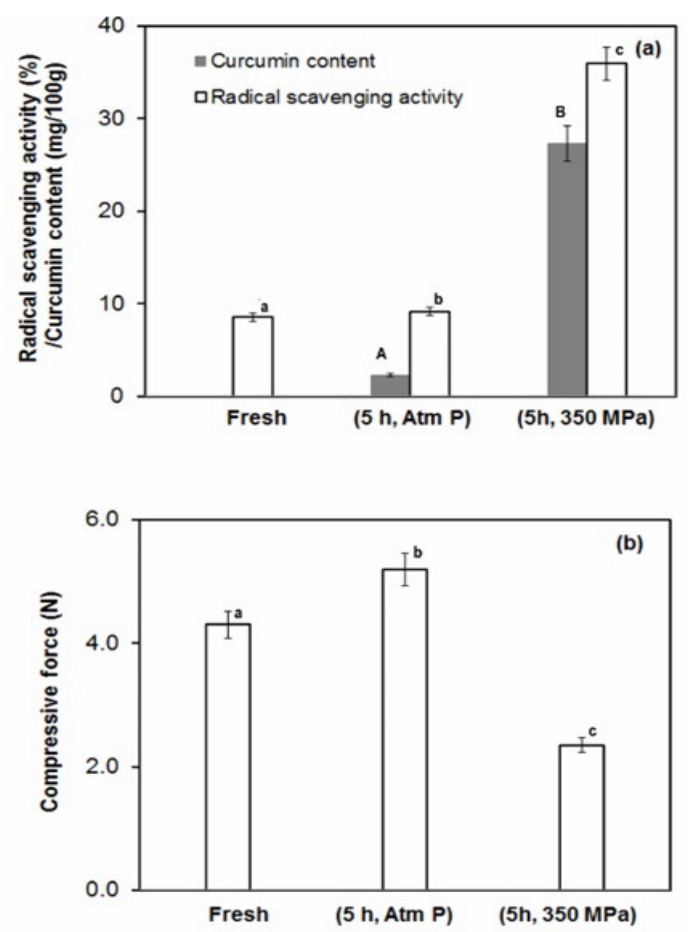

Figure 5: (a) The free radical scavenging activity (\%) and curcumin content $(\mathrm{mg} / 100 \mathrm{~g})$ of fresh, pressure treated $(350 \mathrm{MPa}$ for $10 \mathrm{~min})$ and untreated pineapple slices. (b) variation of compression force required to puncture the pineapple slices (fresh, untreated and pressure treated).

\section{Conclusion}

High pressure pretreatment of pineapple slices exhibited an increase in the infused curcuminoids as compared to ambient condition $(0.1 \mathrm{MPa})$, besides enhancing the mass transfer rates of moisture and solid leading to the decrease in process time. Highest incorporation of curcuminoids infusion in pineapple slices was achieved in case when the concentration of osmotic solution was minimum i.e., $0^{\circ}$ Brix. In addition, the present work confirmed the possibility of high pressure treatment for the development of foods with enhanced infusion of bioactive compounds. The study may be useful in optimizing process parameters depending on the extent of infusion of bioactive compounds required for the product development. 


\begin{tabular}{|c|c|c|c|c|c|c|c|c|c|c|c|c|c|c|c|}
\hline \multirow{2}{*}{ Parameters } & \multicolumn{5}{|c|}{$\begin{array}{c}\text { Mass Transfer Coefficient } \\
\left(\text { Kew, Kes or Kec } \times 10^{-9} \mathrm{~m}^{2} / \mathrm{s}\right)\end{array}$} & \multicolumn{5}{|c|}{$\begin{array}{c}\text { Diffusion Coefficient } \\
\text { (Dew, Des or Dec } \times 10^{-9} \mathrm{~m}^{2} / \mathrm{s} \text { ) }\end{array}$} & \multicolumn{5}{|c|}{$\begin{array}{c}\text { Equilibrium Content } \\
(\mathrm{x} \propto \mathrm{w}, \mathrm{x} \infty \mathrm{s} \mathrm{kg} / \mathrm{kg} ; \text { or } x \propto \mathrm{cmg} / \mathbf{1 0 0 g})\end{array}$} \\
\hline & $0 \%$ & $40 \%$ & $50 \%$ & $60 \%$ & $70 \%$ & $0 \%$ & $40 \%$ & $50 \%$ & $60 \%$ & $70 \%$ & $0 \%$ & $40 \%$ & $50 \%$ & $60 \%$ & $70 \%$ \\
\hline \multicolumn{16}{|l|}{ Curcuminoids } \\
\hline Without HPP & $0.87^{\mathrm{a}}$ & $(0.72)^{\mathrm{b}}$ & $(0.65)^{\mathrm{c}}$ & $(0.32)^{d}$ & $(0.23)^{\mathrm{e}}$ & $0.86^{\mathrm{a}}$ & $(0.69)^{\mathrm{b}}$ & $(0.62)^{\mathrm{c}}$ & $(0.43)^{d}$ & $(0.31)^{\mathrm{e}}$ & $2.92^{\mathrm{a}}$ & $(2.20)^{b}$ & $(1.71)^{\mathrm{c}}$ & $(0.97)^{\mathrm{d}}$ & $(0.66)^{c}$ \\
\hline With HPP & $1.86^{\mathrm{f}}$ & $(0.95)^{\mathrm{g}}$ & $(0.82)^{\mathrm{h}}$ & $(0.49)^{\mathrm{i}}$ & $(0.42)^{\mathrm{i}}$ & $1.53^{\mathrm{f}}$ & $(1.42)^{\mathrm{g}}$ & $(0.82)^{\mathrm{h}}$ & $(0.68)^{\mathrm{i}}$ & $(0.64)^{i}$ & $24.64^{f}$ & $(15.42)^{\mathrm{g}}$ & $(14.80)^{\mathrm{h}}$ & $(12.25)^{\mathrm{i}}$ & $(9.37)^{i}$ \\
\hline \multicolumn{16}{|l|}{ Moisture } \\
\hline Without HPP & $(0.92)^{\mathrm{a}}$ & $0.97^{\mathrm{a}}$ & $1.15^{\mathrm{b}}$ & $1.17^{\mathrm{b}}$ & $1.23^{\mathrm{c}}$ & $0.12^{\mathrm{a}}$ & $0.48^{\mathrm{b}}$ & $0.97^{\mathrm{c}}$ & $1.16^{\mathrm{d}}$ & $1.17^{\mathrm{d}}$ & $0.95^{\mathrm{a}}$ & $(0.80)^{\mathrm{b}}$ & $(0.72)^{c}$ & $(0.66)^{d}$ & $(0.58)^{c}$ \\
\hline With HPP & $(1.07)^{\mathrm{d}}$ & $1.09^{\mathrm{e}}$ & $1.30^{\mathrm{f}}$ & $1.35^{\mathrm{g}}$ & $1.57^{\mathrm{h}}$ & $0.55^{\mathrm{e}}$ & $1.02^{\mathrm{f}}$ & $1.11^{\mathrm{g}}$ & $1.52^{\mathrm{h}}$ & $1.68^{\mathrm{i}}$ & $0.96^{\mathrm{a}}$ & $(0.75)^{\mathrm{f}}$ & $(0.62)^{\mathrm{g}}$ & $(0.52)^{\mathrm{h}}$ & $(0.45)^{i}$ \\
\hline \multicolumn{16}{|l|}{ Solids } \\
\hline Without HPP & $(1.12)^{\mathrm{a}}$ & $1.17^{\mathrm{a}}$ & $1.29^{\mathrm{b}}$ & $1.39^{\mathrm{c}}$ & $1.47^{\mathrm{d}}$ & $0.26^{\mathrm{a}}$ & $1.04^{\mathrm{b}}$ & $1.18^{\mathrm{c}}$ & $1.34^{\mathrm{d}}$ & $1.42^{\mathrm{e}}$ & $2.20^{\mathrm{a}}$ & $5.61^{\mathrm{b}}$ & $7.33^{\mathrm{c}}$ & $10.53^{\mathrm{d}}$ & $12.45^{\circ}$ \\
\hline With HPP & $(1.00)^{\mathrm{e}}$ & $1.29^{\mathrm{f}}$ & $1.39^{\mathrm{g}}$ & $1.44^{\mathrm{h}}$ & $1.72^{\mathrm{i}}$ & $0.40^{\mathrm{f}}$ & $1.14^{\mathrm{g}}$ & $1.55^{\mathrm{h}}$ & $1.60^{\mathrm{i}}$ & $1.75^{\mathrm{j}}$ & $1.24^{\mathrm{f}}$ & $6.99^{\mathrm{g}}$ & $11.67^{\mathrm{h}}$ & $15.89^{\mathrm{i}}$ & $16.45^{\mathrm{j}}$ \\
\hline
\end{tabular}

Table 1: Diffusion coefficient for moisture, solid and curcuminoids content during osmotic dehydration with and without application of high pressure (350 MPa/10 min).

The values of diffusion coefficients in the parenthesis indicate the absorption of water from surrounding solution to the pineapple slices. The corresponding values for solids indicate the loss of solids from pineapple slices to the surrounding medium. The values without parenthesis indicate the vice versa. The groups containing different letters in the same row (with respect to treatment) and same column (with respect to concentration) are found to be statistically significant at $p \leq 0.05$. The statistical significance between groups were determined using a one-way Analysis of Variance (ANOVA) followed by Turkey-Kramer test, with $\mathrm{p} \leq 0.05$ indicating significance, using MS-Excel.

\section{Acknowledgement}

The Senior Research Fellowship (INSPIRE) provided to Ms. Jincy M. George by Department of Science and Technology, New Delhi, Government of India is sincerely acknowledged.

\section{Reference}

1. Rózek A, Achaerandio I, Güell C, López F, Ferrando M (2009) Grape phenolic impregnation by osmotic treatment: influence of osmotic agent on mass transfer and product characteristics. Journal of Food Engineering 94: 59-68.

2. Alzamora SM, Salvatori D, Tapia MS, López-Malo A, Welti-Chanes J, et al. (2005) Novel functional foods from vegetable matrices impregnated with biologically active compounds. Journal of Food Engineering 67: 205214.

3. Silva KS, Fernandes MA, Mauro MA (2014) Effect of calcium on the osmotic dehydration kinetics and quality of pineapple. Journal of Food Engineering 134: 37-44.

4. Rózek A, Archaerandio L, Güella C, López F, Ferrando M (2010) Use of commercial grape phenol extracts to supplement solid foodstuff. LWTFood Science and Technology 43: 623-631.

5. Rózek A, García-Pérez JV, López F, Güell C, Ferrando M (2010b) Infusion of grape phenolics into fruits and vegetables by osmotic treatment: Phenolic stability during air drying. Journal of Food Engineering 99: 142-150.

6. Hironaka K, Kikuchi M, Koaze H, Sato T, Kojima M, et al. (2011) Ascorbic acid enrichment of whole potato tuber by vacuum-impregnation. Food Chemistry 127: 1114-1118.

7. Nagai LY, Santos AB, Faria FA, Boscolo M, Mauro MA (2015) Osmotic Dehydration of mango with ascorbic acid impregnation: Influence of process variables. Journal of Food Processing and Preservation 39: 384-393.

8. Salazar-López EI, Jiménez M, Salazar R, Azuara E (2015) Incorporation of Microcapsules in pineapple intercellular tissue using osmotic dehydration and microencapsulation method. Food and Bioprocess Technology 8: 1699-1706.

9. Jiménez-Hernández J, Estrada-Bahena EB, Maldonado-Astudillo YI, Talavera Mendoza O, Arámbula-Villa G, et al. (2017) Osmotic dehydration of mango with impregnation of inulin and piquin-pepper oleoresin. LWTFood Science and Technology 79: 609-615.
10. Neri L, Biase LD, Sacchetti G, Mattia CD, Santarelli V, et al. (2016) Use of vacuum impregnation for the production of high quality fresh-like apple products. Journal of Food Engineering 179: 98-108.

11. Lima MMD, Tribuzi G, Souza JAR, Souza IG, Laurindo JB, et al. (2016) Vacuum impregnation and drying of calcium-fortified pineapple snacks. LWT-Food Science and Technology 72: 501-509.

12. Şahin U, Öztürk HK (2016) Effects of Pulsed Vacuum Osmotic $€$ Dehydration (PVOD) on drying kinetics of figs (Ficus carica L). Innovative Food Science and Emerging Technologies 36: 104-111.

13. Mahadevan S, Nitin D, Salvi D, Karwe MV (2015) High-pressure enhanced infusion: influence of Process parameters. Journal of Food Process Engineering 38: 601-612.

14. Mahadevan S, Salvi D, Karwe MV (2016) High pressure-enhanced infusion in fresh and frozen-thawed cranberries: a comparative study. Journal of Food Process Engineering 39: 53-60.

15. George JM, Selvan TS, Rastogi NK (2016) High-pressure-assisted infusion of bioactive compounds in apple slices. Innovative Food Science \& Emerging Technologies 33: 100-107.

16. Dermesonlouoglou E, Zachariou I, Andreou V, Taoukis PS (2016) Effect of pulsed electric fields on mass transfer and quality of osmotically dehydrated kiwifruit. Food and Bioproducts Processing 100: 535-544.

17. Yildiz H, Icier F, Eroglu S, Dagci G (2016) Effects of electrical pretreatment conditions on osmotic dehydration of apple slices: Experimental investigation and simulation. Innovative Food Science \& Emerging Technologies 35: 149-159.

18. Moreno J, Gonzales M, Zúñiga P, Petzold G, Mella K, et al. (2016) Ohmic heating and pulsed vacuum effect on dehydration processes and polyphenol component retention of osmodehydrated blueberries (cv. Tifblue). Innovative Food Science \& Emerging Technologies 36: 112-119.

19. Moreno J, Espinoza C, Simpson R, Petzold G, Nuñez H, et al. (2016) Application of ohmic heating/vacuum impregnation treatments and air drying to develop an apple snack enriched in folic acid. Innovative Food Science \& Emerging Technologies 33: 381-386.

20. Bellary AN, Sowbhagya HB, Rastogi NK (2011) Osmotic dehydration assisted impregnation of curcuminoids in coconut slices. Journal of Food Engineering 105: 453-459.

21. Rastogi NK (2011) Opportunities and challenges in application of ultrasound in food processing. Critical Reviewes in Food Science and Nutrition 51: 705-722. 
22. Oladejo AO, Ma H (2016) Optimisation of ultrasound-assisted osmotic dehydration of sweet potato (Ipomea batatas) using response surface methodology. Journal of the Science of Food and Agriculture 96: 3688-3693.

23. Barman N, Badwaik LS (2017) Effect of ultrasound and centrifugal force on carambola (Averrhoa carambola L.) slices during osmotic dehydration. Ultrasonics Sonochemistry 34: 37-44.

24. Farr D (1990) High-pressure technology in food industry. Trends in Food Science \& Technology 1: 14-16.

25. Dörnenburg H, Knorr D (1993) Cellular permeabilisation of cultured plant tissues by high electric field pulses or ultra high pressure for recovery of secondary metabolites. Food Biotechnology 7: 35-48.

26. Rastogi NK, Niranjan K (1998) Enhanced mass transfer during osmotic dehydration of high pressure treated pineapple. Journal of Food Engineering 63: $508-511$.

27. Sopanangkul A, Ledward DA, Niranjan K (2002) Mass transfer during sucrose infusion into potatoes under high pressure. Journal of Food Science 67: $2217-2220$.

28. Ahromrit A, Ledward DA, Niranjan K (2006) High pressure induced water uptake characteristics of Thai glutinous rice. Journal of Food Engineering 72: $225-233$.

29. Villacis MF, Rastogi NK, Balasubramaniam VM (2008) Effect of high pressure on moisture and $\mathrm{NaCl}$ diffusion into turkey breast. LWT- Food Science and Technology 41: 836-844.

30. Sila DN, Smout C, Vu TS, Hendrickx ME (2004) Effects of high-pressure pretreatment and calcium soaking on the texture degradation kinetics of carrots during thermal processing. Journal of Food Science 69: 205-211.

31. Duvetter T, Fraeye I, Van Hoang T, Van Buggenhout S, Verlent I, et al (2005) Effect of pectinmethylesterase infusion methods and processing techniques on strawberry firmness. Journal of Food Science 70: 383-388.

32. Fraeye I, Knockaert G, Van Buggenhout S, Duvetter T, Hendrickx M, (2010) Enzyme infusion prior to thermal/high pressure processing of strawberries: Mechanistic insight into firmness evolution. Innovative Food Science \& Emerging Technologies 11: 23-31.

33. Imaida K, Fukushima S, Shirui T, Ohtani M, Nakanishi K, et al. (1983) Promoting activities of butylated hydroxyanisole and butylated hydroxytoluene on 2-stage urinary bladder carcinogenesis and inhibition of gamma-glutamyl transpeptidase-positive foci development in the liver of rats. Carcinogenesis 4: 895-899.

34. Govindarajan VS (1980) Turmeric--chemistry, technology and quality. Critical Reviewes in Food Science and Nutrition 12: 199-301.

35. Joe B, Vijaykumar M, Lokesh BR (2004) Biological properties of curcumin-cellular and molecular mechanisms of action. Critical Reviewes in Food Science and Nutrition 44: 97-111.
36. WHO (2000) Evaluation of certain food additives and contaminants. FAO/ WHO Expert committee report on food additives. WHO, Geneva, Switzerland.

37. Kalpravidh RW, Siritanaratkul N, Insain P, Charoensakdi R, Panichkul N, et al. (2010) Improvement in oxidative stress and antioxidant parameters in beta-thalassemia/ $\mathrm{Hb} \mathrm{E}$ patients treated with curcuminoids. Clinical Biochemistry $43:$ 424-429.

38. Skrzypezac-Jankun E, McCabe NP, Selman SH, Jankun J (2000) Curcumin inhibits lipoxygenase by binding to its central cavity: theoretical and $\mathrm{X}$-ray evidence. International Journal of Molecular Medicine 6: 521-526.

39. Heng MC, Song MK, Harker J, Heng MK (2000) Drug-induced suppression of phosphorylase kinase activity correlates with resolution of psoriasis as assessed by clinical, histological and immunohistochemical parameters. The British Journal of Dermatolology 143: 937-949.

40. Arun N, Nalini N (2002) Efficacy of turmeric on blood sugar and polyol pathway in diabetic albino rats. Plant Foods for Human Nutrition 57: 4152.

41. Singh R, Chandra R, Bose M, Luthra PM (2002) Antibacterial activity of Curcuma longa rhizome extract on pathogenic bacteria. Current Science 83: $737-740$

42. Aggarwal BB, Kumar A, Bharti AC (2003) Anticancer potential of curcumin: preclinical and clinical studies. Anticancer Research 23: 363-398.

43. Sowbhagya H, Smitha S, Sampathu SR, Krishnamurthy N, Bhattacharya S (2005) Stability of water-soluble turmeric colorant in an extruded food product during storage. Journal of Food Engineering 67: 367-371.

44. Way R (1985) Official analytical methods of the American Spice Trade Association, ( $3^{\text {rd }}$ edn). American Spice Trade Association, Washington DC, USA.

45. Crank J (1975) The mathematics of diffusion. Clarendon Press, Oxford, UK.

46. Rastogi NK, Raghavarao KSMS, Niranjan K, Knorr D (2002) Recent developments in osmotic dehydration: methods to enhance mass transfer. Trends in Food Science \& Technology 13: 48-59.

47. Perry RH, Green DW, Maloney JO (1984) Perry's Chemical Engineer's Handbook, ( $6^{\text {th }}$ edn). McGraw Hill, New York, USA.

48. Zheng H, Lu H, Zheng Y, Lou H, Chen C (2010) Automatic sorting of Chinese jujube (Zizyphus jujube Mill. cv. 'hongxing') using chlorophyll fluorescence and support vector machine. Journal of Food Engineering 101: 402-408.

49. Lin DS, Leonard SW, Lederer C, Traber MG, Zhao Y (2006) Retention of fortified vitamin $\mathrm{E}$ and sensory quality of fresh-cut pears by vacuum impregnation with honey. Journal of Food Science 71: 553-559. 